\title{
Pluralism and Democratic Participation: What Kind of Citizen are Citizens Invited to be?
}

\author{
Oliver Escobar \\ Dr.; Lecturer in Public Policy and Co-Director of What Works Scotland, \\ University of Edinburgh, Scotland (UK) \\ oliver.escobar@ed.ac.uk
}

\begin{abstract}
Classic pragmatism laid the foundations for a practice-based notion of citizenship that views democracy as a fragile accomplishment in need of constant self-actualisation. This article revisits this heritage to explore different notions of pluralism and democratic participation developed over the last century. Drawing on James and Dewey, the article interrogates how different understandings of democracy deal with pluralism and the meaning of democratic life. The focus is on three prominent models in contemporary democratic theory and practice, namely: representative, participatory and deliberative. The purpose is to review different ways of thinking and enacting citizen participation and explore key distinctions, overlaps and productive tensions. The conclusion argues that a vibrant democratic ecology requires combining the practices that underpin these models in order to develop deeper, and more sustainable, forms of citizenship and democratic life.
\end{abstract}

\section{Keywords}

democracy - participation - deliberation - citizenship

\section{Introduction}

The old saying that the cure for the ills of democracy is more democracy is no apt if it means ... introducing more machinery of the same kind ... But the phrase may also indicate the need of returning to the 
idea itself, of clarifying and deepening our apprehension of it, and of employing our sense of its meaning to criticize and remake its political manifestations.

JOHN DEWEY (1984, p. 325)

The current spread of democracy around the world is unprecedented, and so is the level of civic aspiration, expectation and discontent with current institutional practices and notions of citizenship (Dalton, 2004; Norris, 2002, 2011). Democracy is an idea that has been continuously constructed, contested, fought over, implemented and revised (Saward, 2003, p. viii). This article outlines different notions of pluralism and democratic participation developed over the last century. The purpose is to explore three different ways of thinking and enacting democracy, including key distinctions, areas of overlap and productive tensions. In particular, the article analyses the participatory and deliberative turns in democratic theory and practice, and draws on the work of classic pragmatists William James and John Dewey in order to unpack alternative forms of pluralism and democratic participation.

James' pluralism recognises that natural and social worlds are multiple, diverse and evolving, and is suspicious of attempts to represent them as unitary or absolute (Bernstein, 2010, pp. 53-69). His pluralism, therefore, was not merely descriptive but entailed ethical concerns regarding how to deal with the plurality of worlds and beings. He was particularly critical of "the blindness with which we are all afflicted in regard to the feelings of creatures and people different from ourselves" (James, 1997, p. 629). Pluralist political theory after James has approached moral, ethical and cultural pluralism as "an empirical, political reality", and "has imagined numerous paths toward the development of an acceptance of varied values, cultures, and ways of life" (Schlosberg, 2008, p. 142). Many of those paths have been grounded on alternative views of what democratic participation could and should look like.

Dewey was a pioneer in questioning orthodox understandings of democracy and thus refused to reduce its meaning to a political system or a form of government (Dewey, 1916, p. 1419). Instead, he proposed thinking about democracy as "a way of life" (Dewey, 1937, p. 457), and this invited profound questions about the role of citizens and communities in democratic participation (see Dewey, 1927). Therefore, following James and Dewey, I will interrogate how different understandings of democracy deal with pluralism and the meaning of democratic life. To do so, I explore three models that have become prominent in contemporary democratic theory and practice, namely: representative, participatory and deliberative. 


\begin{tabular}{|c|c|c|c|}
\hline & $\begin{array}{l}\text { Representative } \\
\text { democracy }\end{array}$ & $\begin{array}{l}\text { Participatory } \\
\text { democracy }\end{array}$ & $\begin{array}{l}\text { Deliberative } \\
\text { democracy }\end{array}$ \\
\hline $\begin{array}{l}\text { Notion of } \\
\text { democratic } \\
\text { participation }\end{array}$ & $\begin{array}{l}\text { Voting in elections } \\
\text { to choose between } \\
\text { competing elites }\end{array}$ & $\begin{array}{l}\text { Taking part in } \\
\text { collective action } \\
\text { and decision- } \\
\text { making in civic } \\
\text { and/or official } \\
\text { spheres }\end{array}$ & $\begin{array}{l}\text { Engaging in } \\
\text { deliberation about } \\
\text { public issues and } \\
\text { policies }\end{array}$ \\
\hline Notion of pluralism & $\begin{array}{l}\text { Aggregative / } \\
\text { competitive }\end{array}$ & Engaged / critical & $\begin{array}{l}\text { Discursive / } \\
\text { consensual }\end{array}$ \\
\hline $\begin{array}{l}\text { How are publics } \\
\text { made? }\end{array}$ & $\begin{array}{l}\text { By aggregating } \\
\text { individual } \\
\text { preferences } \\
\text { through electoral } \\
\text { contests and } \\
\text { interest groups }\end{array}$ & $\begin{array}{l}\text { Through processes } \\
\text { of collective } \\
\text { association, } \\
\text { collaboration, } \\
\text { struggle and civic } \\
\text { education }\end{array}$ & $\begin{array}{l}\text { Through public } \\
\text { deliberation } \\
\text { that transforms } \\
\text { individual } \\
\text { preferences into } \\
\text { public reasons }\end{array}$ \\
\hline $\begin{array}{l}\text { What kind of } \\
\text { citizen are citizens } \\
\text { invited to be? }\end{array}$ & $\begin{array}{l}\text { Occasional voter; } \\
\text { member of interest } \\
\text { group }\end{array}$ & $\begin{array}{l}\text { Ongoing } \\
\text { participant in } \\
\text { civic and official } \\
\text { processes }\end{array}$ & $\begin{array}{l}\text { Considered } \\
\text { deliberator }\end{array}$ \\
\hline $\begin{array}{l}\text { Examples of } \\
\text { institutional } \\
\text { mechanisms }\end{array}$ & Elections & $\begin{array}{l}\text { Participatory } \\
\text { Budgeting }\end{array}$ & Mini-publics \\
\hline
\end{tabular}

These models are not mutually exclusive and overlap in contemporary practice. There is also a chronological dimension to their evolution, and indeed they partly emerged in response to previous models. The key differences between them are their emphases, assumptions and aspirations with regard to democratic life. This article is structured according to a framework designed to tease out key distinctions. Accordingly, for each model, I will explore the following dimensions (summarised in Table 1 and unpacked in subsequent sections):

- The notion of democratic participation that underpins each model. That is, what does it mean to participate in democracy?

- How is pluralism understood and addressed, and how does this shape democratic participation? 
- How are publics constructed? Publics and communities are not simply preexisting entities, but get made through the ways in which they are imagined, summoned, assembled and mobilised (Barnett, 2008).

- The role of citizens. Different understandings of democracy imply different assumptions about citizenship, and shape the opportunities that people get to participate. Therefore, for each model, I will ask: What kind of citizen are citizens invited to be?

- Institutional mechanisms. The emblematic mechanism for participation in representative democracy is the electoral contest. Since this is well known, I will focus instead on two democratic innovations that epitomise participatory and deliberative practices, namely: participatory budgeting and mini-publics.

\section{Representative Democracy}

In representative democracy citizens elect candidates periodically in order to represent them in institutions and make decisions on their behalf. This understanding was articulated seven decades ago by thinkers such as Schumpeter (1943), who argued that democracy is about competitive elite politics and methods for "selecting leaders, rather than about popular participation in politics as such" (Saward, 2003, p. 56). For its advocates then and now, given the complexities of governance and policymaking, this seems the most "workable form of democracy" (Elstub \& McLaverty, 2014, p. 13). From this perspective, democratic participation is about citizens casting votes and allowing representatives and officials to get on with the business of governing until the next election.

Dahl's work in the 1950s is a key exponent of the dominant notion of pluralism built on the Schumpeterian narrative of democracy. Dahl (1989b) understood pluralism as the aggregation of citizens' interests through diverse political parties and interest groups, so that democracy features multiple centres of power and counters authoritarianism. Furthermore, he considered this to be the distinguishing feature of modern democratic regimes: "What for centuries was held to be the lethal poison of republics, the spirit of faction, is in modern democracies institutionalized in parties and interest groups" (Dahl, 1982, p. 28). In this pluralist model, the accommodation of difference and the resolution of conflict take place through bargaining and exchange amongst the leaders of competing groups (Barber, 2003, p. 144).

The making of publics in representative democracy takes therefore place in aggregative fashion. By aggregating the individual preferences of citizens, 
the goal of electoral participation is to decide what "leaders, rules, and policies will best correspond to the most widely and strongly held preferences" (Young, 2000, p. 19). Accordingly, democracy is a "competitive process" in which political parties "attempt to satisfy the largest number of people's preferences", and publics are constructed on the basis of like-minded citizens organising interest groups in order to "influence the actions of parties and policy-makers once they are elected" (Ibid.).

The role of citizens in this conception of democracy is minimalist. They are invited to be voters, and as Schumpeter put it, "once they have elected an individual, political action is his business and not theirs" (Saward, 2003, p. 41). Therefore, citizens are offered to be mainly "spectators in the game of politics", which remains the preserve of political and interest group elites (Dryzek, 1990, p. 120). It is difficult to overstate the predominance of this way of thinking and enacting democracy. Today, in the eyes of many, democracy means mostly representative democracy (Hibbing \& Theiss-Morse, 2002; cf. Neblo, Esterling, Kennedy, Lazer, \& Sokhey, 2010).

Nonetheless, increasing recognition of the shortcomings of this model has opened up space for alternatives that seek to enhance representative democracy by developing new meanings and practices. This has been particularly driven by the demands of contemporary governance and policymaking. Warren (2009, p. 6) highlights the growing incapacities of representative democracy with respect to policy development and implementation. Under the standard model, citizens elect representatives to make policy on their behalf, who then direct administrators to further develop it. However, Warren explains, those underpinning linkages are broken by the realities of contemporary governance. Firstly, territorial electoral constituencies seldom match issue constituencies. Secondly, electoral systems "only roughly reflect citizen preferences, and they do so in highly aggregated, information-poor ways". Thirdly, legislatures have "very low policy-making capacities, and so pass most decisions to executives ... and agencies", which are "often left to guess what constituents want". Finally, bureaucratic forms of policy development also feature "inherent limitations" stemming from hierarchical rigidity and enormous technical and political complexity. In this context, policy-makers increasingly "speak the language of trust, collaboration" and citizen engagement to compensate "for low global legitimacy of electoral democracy by generating legitimacy ... issue by issue, policy by policy, and constituency by constituency" (Warren, 2009, pp. 7-8).

Accordingly, conventional liberal notions of "representative democracy plus techno-bureaucratic administration" (Fung \& Wright, 2003b, p. 3) are being challenged on various grounds. For Dalton (2004, p. 1), the main challenge 
comes from citizens, who seem increasingly "distrustful of politicians, sceptical about democratic institutions, and disillusioned about how the democratic process functions". Furthermore, the intensification of social complexity, coupled with new hierarchies of knowledge and expertise, are deemed to contribute to deeper and subtler levels of democratic deficit (Fischer, 2009). Putnam (2000) has also illustrated the deterioration of the relational fabric of community life -or "social capital"-arguing that this hinders democratic participation.

While some have questioned such narratives of decline by documenting the emergence of alternative forms of participation (e.g. Castells, 2012; Norris, 2002), governments and public agencies have nonetheless increased efforts to institutionalise new participatory and deliberative processes (Escobar, 2014, pp. 3-10). Accordingly, collaborative governance and public participation arrangements are presented as strategies to counter democratic deficits, deal with complex issues, increase problem-solving capacity, foster social capital, and restore legitimacy to policy-making processes (Callon, Lascoumes, \& Barthe, 2009; De Souza Briggs, 2008; Fischer, 2000). Indeed, representative democracy has been increasingly infused with ideas and practices of participatory democracy.

\section{Participatory Democracy}

Although debates about participatory democracy can be traced back to Athenian democracy, the narratives highlighted here were shaped in the past century. For example, Dewey was a strong critic of the "democratic elitism" that underpins mainstream narratives of representative democracy (Bernstein, 2010, p. 74). He saw elitism as central to the demise of democracy and the advance of elite-driven populism and totalitarian regimes (Dewey, 1937, p. 467):

Everywhere there are waves of criticism and doubt as to whether democracy can meet pressing problems ... Wherever it has fallen, [democracy] had not become part of the bone and blood of the people in daily conduct of its life. Democratic forms were limited to Parliament, elections and combats between parties. What is happening proves conclusively, I think, that unless democratic habits of thought and action are part of the fiber of a people, political democracy is insecure. It can not stand in isolation. It must be buttressed by the presence of democratic methods in all social relationships. 
Dewey understood democracy as more than a form of government. He saw it as a way of life and placed at its heart "the necessity for the participation of every mature human being in formation of the values that regulate the living of [people] together", thus arguing that this is "necessary from the standpoint of both the general social welfare and the full development of human beings as individuals" (Dewey, 1937, p. 457). The revival of this participatory idea of democracy started in the 1960 s (e.g. Pateman, 1970). It can be broadly defined as a form of democracy that enables extensive participation of citizens in ongoing decision-making, whether it is at national or local level, or within communities or organisations (Saward, 2003, p. 149). Whereas representative democracy leaves politics to specialists and experts, participatory democracy compels citizens to encounter other citizens without intermediaries, and therefore politics is seen as the art of participating in planning, coordinating and enacting collective futures (Barber, 2003, pp. 152, 153).

Participatory democrats come in many stripes, but they share a critique of the aggregation-based logic of pluralism in representative democracy (Barber, 2003; Hirst, 1990, pp. 38-56; Mouffe, 1992; Pateman, 1970). That is, they argue that aggregating citizens' preferences through interest groups and political parties alone may look neutral but "in practice supports and serves the powerful", that is, those most capable of mobilising resources to support their interests (Dryzek, 2010, p. 91). Their contention is that this can subsume or ignore difference and conflict, resulting in the exclusion of citizens, values and perspectives -especially those of marginalised and oppressed groups. Accordingly, participatory democrats start from the recognition that there are multiple legitimate ways of being, experiencing and shaping the world, but they go beyond notions of pluralism where that multiplicity is to be aggregated through competition rather than engaged through participation.

For instance, radical pluralists like Mouffe (1996, p. 246) argue that pluralism is not merely a fact "that we must bear grudgingly or try to reduce". Instead, she advocates a pluralism that "gives a positive status to differences and refuses the objective of unanimity and homogeneity which is always revealed as fictitious and based on acts of exclusion" (Ibid.). Nonetheless, she criticises "extreme pluralism" that uncritically values all differences, and proposes limits because there are certain differences that are "constructed as relations of subordination and should therefore be challenged" (Mouffe, 1996, p. 247). From this perspective, to engage across their differences, citizens should ideally embrace a "democratic attitude that converts antagonism into agonism, fighting into critical engagement, enemies into adversaries who are treated with respect" (Dryzek, 2010, p. 92). 
The notion of pluralism that traverses different versions of participatory democracy chimes well with James' calls for critical engagement with different viewpoints and worldviews. His "engaged pluralism" eschews the relativism of incommensurable frameworks and paradigms, and demands that citizens "reach out to the points of contact where we can critically engage with each other" (Bernstein, 2010, p. 62). Accordingly, participatory democrats dispute the idea that conflict is intractable and can only be addressed through aggregation, competition, bargaining and toleration. Instead, they propose "a politics that can transform conflict into cooperation through citizen participation, public deliberation, and civic education" (Barber, 2003, p. 135).

If representative democracy imagines 'the public' as forming itself through electoral contests and interest group dynamics, participatory democracy imagines a multiplicity of publics developed through processes of collective association, collaboration, struggle and civic education. For Dewey (1927, pp. 131, 137,142 ), the 'general public' is a potentially paralysing abstraction. Only when publics are assembled around specific issues, and embodied locally, they can become democratic agents: "We lie ... in the lap of an immense intelligence. But that intelligence is dormant and its communications are broken, inarticulate and faint until it possesses the local community as its medium" (Dewey, 1927, p. 219). Participatory democrats have since emphasised 'the local' as the key site for democratic participation (e.g. Barber, 2003; De Souza Briggs, 2008). This entails decentralisation and devolution of power across social and policy worlds. For instance, in Hirst's vision (1997, p. 64), a "pluralist state" would exist to "protect and serve the self-governing associations". Accordingly, participatory democrats have often emphasised extending participation in decision-making to other processes and institutions in society -e.g. workplaces, family-and not just the state (Dryzek, 1990, p. 220; Pateman, 1970). This stems from the view that social and economic equality are important to democracy, alongside "narrower views of political equality" based on voting rights (Saward, 2003, p. 72).

The kind of citizen that citizens are invited to be in participatory democracy departs considerably from the minimalist role offered by the Schumpeterian model of representative democracy. Nonetheless, critics often point out that taking on this enhanced role may be too much to ask of citizens. A century ago, Lippman (1927, pp. 54-55) argued that most citizens are likely to be ill-informed, gullible, disinterested, partisan and lacking knowledge, creativity and problem-solving capacity. Consequently, his solution was to leave politics to leaders and experts. This spurred an emblematic debate with Dewey, who counter-argued that "the cure for the ills of democracy was a more radical and committed democracy" (Bernstein, 2010, p. 80). Dewey 
consistently defended his "faith in the capacity of human beings for intelligent judgement and action if the proper conditions are furnished" (quoted in Bernstein, 2010, p. 75).

This developmental understanding of citizen participation became a defining feature of participatory democracy. For instance, Pateman (1970, p. 43) emphasised that participation not only produced outputs in the form of policies and decisions, but also generated educative effects that contributed to the "development of the social and political capacities of each individual". This highlights two important dimensions in participatory democracy. On the one hand, the sense of efficacy that can be developed by citizens "taking advantage of opportunities for genuine participation in decisions affecting their lives" (Saward, 2003, p. 71). On the other, the view that citizens are not "pre-packed bundles of fixed preferences and fixed propensities" but they have potential that can be "nurtured and shaped, for their benefit and for that of their societies" (Saward, 2003, p. 72). The Lippman/Dewey debate is still very much alive today, as anyone involved in developing engagement processes knows too well (see Escobar, 2014, pp. 213-241). However, practices of participatory democracy, despite pitfalls and shortcomings, demonstrate that citizens can be capable problem-solvers and policymakers (De Souza Briggs, 2008; Fischer, 2000, 2009; Fung, 2004; Fung \& Wright, 2003a; Smith, 2009).

The ideals of participatory democracy have informed the mushrooming of engagement processes across the world (e.g. www.participedia.net). An emblematic exemplar of the translation of those ideals into institutional practices is the case of participatory budgeting ( $\mathrm{PB})$. $\mathrm{PB}$ originated in the Brazilian city of Porto Alegre in the late 1980s, when the newly elected government of the Workers Party sought to develop mechanisms for citizen participation in local governance. This was to fulfil their "pro-poor" electoral commitment (Smith, 2009, p. 35), as well as break with decades of generalised political patronage and civic dissatisfaction with representative institutions in Brazilian political life (Baiocchi, 2005, pp. 9-13). PB is a democratic innovation based on a simple idea: involving citizens in making decisions about public expenditure.

The Porto Alegre process entails a series of periodic assemblies over several months at neighbourhood, district and municipal levels (for an overview see Smith, 2009, p. Chapter 2). Citizens set local priorities at the popular assemblies and then send delegates to the strategic committees, where they work with public officials to make decisions regarding the distribution of resources. Then, the mayor takes the budget to the legislature for formal approval (Baiocchi, 2005, p. 9). The evaluations of the first decade of PB in Porto Alegre highlighted the challenges of introducing this participatory mechanism in the 
face of existing administrative and community activist cultures, but they also noted its remarkable achievements regarding improvements for the poorest areas in a city with over 1.3 million citizens (see for instance Baiocchi, 2005; Sintomer \& Gret, 2005; Wampler, 2007). As Baiocchi (2005, p. 14) explains, up to $21 \%$ of a budget that in 2001 was U.s. $\$ 610$ million was allocated through PB to hundreds of projects that

have contributed to an increase to almost full coverage in sewage and water, a threefold increase in the number of children in municipal schools, and significant increases in the number of new housing units provided to needy families. Porto Alegre's expenditures on certain areas, such as health and housing, are much higher than the national average, and the municipality has tended over the years to spend less in administrative costs.

In 2001, over 16,600 citizens were taking part in РВ (Smith, 2009, p. 1). Remarkably, Р в succeeded in attracting "broad-based participation from the poorer strata of Porto Alegre's citizenry" - with women, ethnic minorities, and low income and low education participants being overrepresented when compared to the city's population- and proved successful in "effectively linking that participation to redistributive outcomes" (Baiocchi, 2005, pp. 14-15). Р B soon became a signature policy of the Workers Party across Brazil, although other parties have sometimes kept it when taking power (Wampler, 2007). Inspired by the 2001 World Social Forum in Porto Alegre, activists and political entrepreneurs took the idea and tried, with variable fortune, to adapt it in other countries (Röcke, 2013). Since then, PB has reached global diffusion with thousands of processes across the globe, although it is important to note that $\mathrm{PB}$ has become a popular label sometimes attached to processes that bear little resemblance to the emancipatory Porto Alegre model (Baiocchi \& Ganuza, 2014).

\section{Deliberative Democracy}

Since the 1990s, deliberative theory and practice have built on, and rekindled, some of the ideals of participatory democracy (for an overview see Elstub, 2010). Indeed, deliberative democracy shares much with its participatory counterpart. The distinguishing feature, however, is its emphasis on communication as the key dimension in democratic participation. This discursive focus is underpinned by the claim that "political decision-making should be 
talk-centric rather than voter-centric" (Elstub \& McLaverty, 2014, p. 1). Deliberative democrats also highlight the inadequacy of "aggregative conceptions", arguing that democracy is more than just counting heads: "it must involve discussion on an equal and inclusive basis, which deepens participants' knowledge of issues, awareness of the interests of others, and the confidence to play an active part in public affairs" (Saward, 2000, p. 5).

Democracy is thus seen not as "a market for the exchange of private preferences" but as a discursive forum for the exchange of public reasons and the creation of public agreements (Parkinson, 2004, p. 379). Ideally, in that forum, "no force except that of the better argument is exercised" (Habermas, 1975, p. 108; for a critique see Shapiro, 1999), and there is room for reasons and emotions through inclusive communication dynamics that enable diverse forms of expression, argumentation and reciprocity (Escobar, 2011; Morrell, 2010; Young, 2000). Crucially, deliberation entails "communication that induces reflection on preferences, values and interests in a non-coercive fashion" (Mansbridge et al., 2010, p. 65). The goal is to facilitate conversations that generate

reasonable, well-informed opinions in which participants are willing to revise preferences in light of discussion, new information, and claims made by fellow participants. Although consensus need not be the ultimate aim of deliberation, and participants are expected to pursue their interests, an overarching interest in the legitimacy of outcomes (understood as justification to all affected) ideally characterizes deliberation.

CHAMBERS, 2003, p. 309

In other words, participants make decisions not by counting what preferences have greater numerical support but "by determining which proposals the collective agrees are supported by the best reasons" (Young, 2000, p. 23). Therefore, deliberative democrats argue that "public deliberation of free and equal citizens" is the core of legitimate decision-making and self-government (Bohman, 1998, p. 401). Moreover, they claim that "deliberation improves the quality and acceptability of collective decisions" (Saward, 2003, p. 147).

The notion of pluralism that underpins deliberative democracy builds on the engaged pluralism previously explored but, again, places further emphasis on the role of discourse in consensus-building. In Table 1, I used the label 'discursive pluralism' to capture the deliberative democrat's assumption that difference and disagreement can be not only expressed but also actively addressed through dialogue and deliberation (Escobar, 2011, pp. 38-44). As Dryzek (2010, p. 93) notes, many pluralist schools agree that pluralism is both 
valuable and problematic, and they "see communication across difference as key to resolution".

Accordingly, Schlosberg (2008, p. 149) argues that, even if incommensurable, values and beliefs can be shared, or at least understood, across differences. However, it is crucial that, echoing earlier references to agonism, addressing conflict does not translate into the dismissal of diversity (Schlosberg, 2008, p. 150). To deal with this careful balance, deliberative democrats prize reciprocity, which means that "citizens must provide reasons in terms that those with whom they disagree can accept" (Dryzek, 2010, p. 102; Gutmann \& Thompson, 1996). Therefore, discursive pluralism implies that difference and disagreement can be productively engaged through deliberation insofar they are communicated in terms that others may recognise as legitimate. Although deliberative democracy often strives for consensus, it acknowledges the inevitability of conflict and the desirability of difference. From this perspective, the key to conflict resolution is "the reconstruction of private or partial interests into publicly defensible norms" through sustained deliberation (Barber, 2003, p. 135; Dryzek, 1990, p. 124).

Deliberative democracy pays considerable attention to how publics are made. It does not treat 'the public' as a given, but emphasises that publics should be developed by engaging citizens with diverse beliefs, values and views in dialogue and deliberation with others. This is a response to the challenge -also levelled against participatory democracy- that most citizens cannot realistically be well informed on public issues, and therefore are incapable of considered judgement on matters of policy and governance. Deliberative democracy seeks to transform citizens' possibly uninformed views and preferences through open and inclusive discussion -in contrast to aggregative electoral procedures that merely register those views and preferences uncritically (Saward, 2003, p. 121).

In deliberative democracy, publics are therefore made through deliberation that transforms private preferences through the discipline of justification that is, deliberators must offer public reasons in support of their alternative ideas about what constitutes the common good in the pursuit of policies and decisions. Public deliberation is thus an open arena for testing ideas, evidence and arguments on their own merits -in contrast to the power dynamics of interest group bargaining.

Diversity and inclusion are crucial to robust public deliberation. Accordingly, demographic diversity plays an important role in ensuring that deliberative processes involve a range of citizens across the social and economic spectrum -e.g. age, gender, ethnicity, income, education. This has been termed 
by Phillips (1995) as the "politics of presence", and the argument is that demographic diversity can help to ensure that a variety of perspectives and experiences are represented in deliberation. However, to avoid the essentialism of assuming that citizens with certain demographic characteristics can in any way be representative of a particular social group, deliberative democrats are increasingly placing emphasis on discursive diversity (see Dryzek \& Niemeyer, 2010). This means including a variety of discourses, that is, worldviews, beliefs, values and ideas articulated through communication. This is based on the idea that a forum that includes 100 participants who are demographically diverse, but actually think and talk similarly, is arguably less diverse -from a deliberative perspective- than a forum with 10 participants who actually express very different viewpoints and worldviews.

The kind of citizen that citizens are invited to be in deliberative settings is that of informed deliberator engaged in sense-making, problem-solving and considered judgement. This shares participatory democracy's belief in the potential of all citizens to engage meaningfully with public affairs. But it also emphasises that the capacity and competence for considered judgement is not only developed through mere participation, but through engagement in communication that features deliberative qualities. For instance, participating in processes that only bring together like-minded people may not foster the kind of exposure to difference and disagreement that deliberative democrats argue can be transformative (e.g. Mutz, 2006; Sunstein, 2009). The learning and shaping of ideas that takes place in inclusive deliberative interaction is, in this view, crucial to develop the kind of informed judgement needed for making public policies and collective decisions.

In practice, deliberative democracy can be understood at a macro or a micro level. The former concerns the "public sphere", which is a space-distinct from the state and the market- for political engagement through discursive interaction (Fraser, 1990, p. 57). This includes the "ebb and flow of public debate carried on in the media, in private conversations, in formal and informal settings, from pubs to parliaments and back again" (Parkinson, 2004, p. 380; Parkinson \& Mansbridge, 2012). In turn, the micro level focuses on forums and processes emerging at the interface between official and public spheres. Most thinking and experimentation regarding deliberative practices has taken place at this micro level. In particular, one democratic innovation -mini-publics- has seen continuous development over the last two decades. In the remainder of this section I introduce mini-publics to illustrate how deliberative ideas have been translated into practices.

The idea of mini-publics was first proposed four decades ago by Dahl (1989a, p. 342) as a mechanism for involving citizens in dealing with public issues. He called it 'minipopulus': an assembly of citizens, demographically representative 
of the larger population, brought together to learn and deliberate on a topic in order to inform public opinion and decision making. A growing number of democratic innovations have proliferated globally based on this idea, from citizens' juries, to planning cells, consensus conferences, deliberative polls and citizen assemblies (for overviews Elstub, 2014; Smith, 2009, pp. 72-110). They have been used to deal with topics ranging from constitutional and electoral reform, to controversial science and technology, and myriad social and policy issues (e.g. health, justice, planning, sectarianism).

Mini-publics are typically made up of quasi-randomly selected citizens, for instance, chosen by lot from the electoral roll or a similar proxy for the relevant population. The principle is that everyone affected by the topic in question has an equal chance of being selected, and this underpins the arguments that can then be made about its legitimacy (Carson \& Martin, 1999). Stratified random sampling is typically used to ensure the inclusion of a range of demographic characteristics from the broader population. The purpose is to assemble a microcosm of 'the public', a mini-public. They vary in size from around twenty participants in citizens' juries to hundreds in deliberative polls. Therefore, smaller mini-publics cannot be representative but still aim to be demographically diverse (Hendriks, 2005, p. 96). The process usually has at least three stages:

- Learning phase. Participants are supported to learn about the topic by scrutinising evidence, views and testimonies presented, for instance, by experts, officials, activists and relevant stakeholders. A Stewarding Board usually oversees the process to ensure that the information and opinion provided are balanced and reflect the variety of perspectives on the issue.

- Deliberative phase. Aided by impartial facilitators, participants then engage in small group deliberation where they reconsider their initial views and preferences on the topic in the light of the evidence and testimonies from the learning phase, but also with respect to the arguments and experiences of their fellow deliberators.

- Decision-making phase. Depending on the topic and type of mini-public, this leads to a particular recommendation or decision articulated in a final report or statement. That is the case in consensus-oriented mini-publics such as citizens' juries, consensus conferences and citizens' assemblies. In research-oriented mini-publics, such as deliberative polls, the aim is not consensus, but measuring through pre- and post- surveys how citizens' preferences may change through learning and deliberation.

Mini-publics offer an innovative way of answering a fundamental question: How would citizens deal with a given issue if they had the time and resources to learn and deliberate about it in order to reach an informed decision? Evidence 
from mini-publics consistently suggests that, when given time and resources to learn and deliberate, citizens can come to grips with complex issues and produce considered recommendations (Elstub, 2014; Grönlund, Bächtiger, \& Setälä, 2014; Roberts \& Escobar, 2015). This section concludes with a snapshot of an emblematic mini-public.

When the issue of electoral reform gained momentum in British Columbia (Canada), the government adopted an unusual approach. Instead of leaving it to political parties -with clear vested interests in the issue- they tasked citizens with reviewing the electoral system and, if judged necessary, propose a new one. Accordingly, the British Columbia Citizens' Assembly on Electoral Reform was formed in 2004, including 160 randomly selected citizens. There were one man and woman -across a range of ages- for each of the 79 electoral districts, plus two Aboriginal participants. Assembly participants were given a stipend for their work. The process involved several weekend assembly sessions over 10 months, and public hearings hosted by the participants in their local communities. The Assembly went through learning, deliberative and decision-making stages, and produced a final recommendation to the British Columbia legislature. The proposal for the Assembly's preferred electoral system was then put to the citizenry through a referendum. In the end, the proposal received considerable public support (57\%) but missed by $3 \%$ the required threshold. To this day, and alongside subsequent constitutional assemblies in Ontario, Netherlands and Ireland, this case remains one of the most ambitious attempts to embody deliberative ideals in a new type of democratic institution (Fournier, van der Kolk, \& Carty, 2011; Warren \& Pearse, 2008).

\section{Conclusions: A Vibrant Ecology of Participation Practices}

Prominent post-war theorists constructed a narrative of democracy that emphasised leadership, competition, aggregation and minimalist citizenship. This understanding of representative democracy became so influential that many subsequent scholars felt no need to justify it. Indeed, it became the mainstream narrative, and the benchmark by which democracy was to be understood, measured and analysed. Accordingly, as Saward (2003, pp. 42-47) explains, important ideological assumptions were built into that narrative and presented as mere descriptions of the 'reality' of democratic politics. Amongst the critics of this narrative, however, were participatory democrats who since the $1960 \mathrm{~s}$ rekindled the pre-war ashes of Dewey's vision for democracy and participation. Participatory democracy grew, in theory and practice, thus permeating mainstream narratives with strong arguments about pluralism, inclusion, and 
citizen empowerment and education. Since the 199os, deliberative democrats built on participatory ideals, but also developed distinct normative and practical dimensions around the communicative fabric of democracy.

In the last two decades, there have been robust theoretical and empirical critiques of participatory and deliberative democracy, and the challenges of turning ideals into practices have become apparent. This has rekindled debates over whether citizens are willing and capable to participate and deliberate (e.g. Fischer, 2000; Hibbing \& Theiss-Morse, 2002; Neblo et al., 2010); how to ensure inclusion and diversity, and their effects on group dynamics (e.g. Mutz, 2006; Sunstein, 2009; Young, 2000); whether participation and deliberation are feasible in the face of interest-based politics (e.g. Forester, 1988; Hendriks, 2011; Shapiro, 1999); whether participatory processes seek enrolment and co-option rather than empowerment (e.g. Cooke \& Kothari, 2001; Cornwall \& Coelho, 2007); whether emancipatory practices are giving way to technocratic or depoliticised participatory processes (Baiocchi \& Ganuza, 2017; Lee, 2015); and the challenge of scaling up deliberation to develop large deliberative systems (Parkinson \& Mansbridge, 2012).

In isolation, none of the three models sketched here are fully satisfactory. Representative democracy, as shown earlier, can be an easy target for criticism. However, as Saward (1998, p. 64) argues, participatory and deliberative democracy can't fully substitute representative democracy, and indeed they often require aggregative mechanisms for resolution and decision-making. Nonetheless, participatory budgeting and mini-publics are good examples of how different understandings of democracy can coalesce into one process that involves participation, deliberation and voting -the core constitutive practices of the three models. Accordingly, these practices can be combined in productive ways. For instance, voting after a deliberative process can combine two important democratic goods: informed and considered decision-making through deep deliberation, and legitimate decision-making through large-scale expression of popular preferences using the ballot.

Therefore, these three ways of understanding democracy overlap and can be enacted in complementary ways by combining and sequencing their constitutive practices. However, it is important to acknowledge their distinctiveness. For example, there can be deliberative democracy without participatory democracy and vice versa. Deliberation can take place amongst political or policy elites (e.g. Steiner, 2004), which is normatively desirable but doesn't fulfil broader participatory ideals of inclusion. By the same token, participation can take place without deliberation, for instance, when citizens engage only with the like-minded, interact on the basis of interest-based bargaining, or take part in protests and boycotts. All of these are of course legitimate courses 
of action in democratic life. But the point is that these different forms of participation can play different functions, and therefore their combination may offer new options that realise a broader range of democratic goods. This is exemplified in the case of participatory budgeting noted earlier on -with citizens and elected representatives engaging in both aggregative and deliberative modes of collective decision-making as part of a process that mobilises people to generate legitimacy, inclusion, transparency, scrutiny and problem-solving. Nonetheless, at the moment, elitist narratives of representative democracy can too easily overhaul participatory and deliberative counter-narratives in practice (Escobar, 2014, pp. 213-242). This much has been learned from ambitious processes like the crowd-sourcing of the new Icelandic constitution, halted in the end by political and interest group elites (Gylfason, 2013).

These models encompass not only different understandings of democracy, but also different democratic aspirations. Therefore, there may be a sense of incompatibility if we simply focus on the ideas and assumptions that underpin them -i.e. the different conceptions of the role of citizens (see Table 1). However, if we focus on practices and mechanisms, then combination seems feasible -i.e. political parties could be more participative, and interest groups could engage more deliberatively. Accordingly, there seems to be potential to develop a representative democracy that is more participatory and deliberative in its mechanisms, and where elections, political parties and interest groups are only one part of a more vibrant ecology of democratic participation. The challenge ahead is to imagine how these three ways of thinking about democracy can be brought together by combining their core practices to enrich political life and co-create better collective futures. The confluence of these three models was already implicit in Dewey's (1916, p. 1542) vision a century ago: “A democracy is more than a form of government; it is primarily a mode of associated living, of conjoint communicated experience".

Although democracy and pluralism go hand in hand, I have shown that their relationship is not straightforward. Both are normative ideas that have evolved through creativity, contestation and practice. Democracy can be seen as a result of, and a response to, pluralism: a way of organising society by building enough common ground -social norms and institutional rules- to enable the respect of differences and their role in articulating, contesting and rearticulating competing ideas of the common good. Pluralists like Connolly (2005) have offered agonistic notions of pluralism that emphasise the acceptance, respect and value of the worldviews, beliefs and positions of others. However, as shown earlier, the way this translates into democratic practices varies. In Rescher's (1993, p. 5) view, the pluralist accepts that "dissensus" is unavoidable in a complex world, and works to "make the world safe for disagreement" and to assemble processes that "make dissensus tolerable if not actually productive". 
Here is where returning to James' engaged pluralism provides a useful foundation for democratic participation. As Bernstein (2010, p. 69) explains, James warned against reification, that is, "the dangers of thinking that groups have fixed identities", for he was "acutely aware of how identities change, develop, and mutate". Consequently, he was critical about "blindly celebrating differences" and just as concerned with "searching for commonalities that can bind us together". The evolving nature of pluralism has subsequently been emphasised by agonistic thinkers who explore "the constitutive tension between already existing diversity and the politics of becoming by which new constituencies struggle to modify the register of legitimate diversity" (Connolly, 2005, p. 69). Consequently, pluralists encourage "a move away from thinking of diversity in terms of individual beliefs" because difference is "both socially constructed and collective" and thus pluralism is always in the making (Schlosberg, 2008, p. 152). As James (2004, p. 53) put it, "knowledge of sensible realities thus comes to life inside the tissue of experience. It is made; and made by relations that unroll themselves in time". For James, the "relations" that enable and shape "knowledge of sensible realities" are made possible by exposure to difference and disagreement. He embraced "the need to see alternatives and imagine other states of mind" (Schlosberg, 2008, p. 150).

This warrants a call for participatory processes, physical and virtual, where citizens can meaningfully engage with those who are different from them those "others" that can be easily dismissed or despised when they remain faceless stereotypes (Escobar, 2011, p. 23). The absence of such forums in the public sphere can have profound consequences because a lack opportunities to be exposed to, and challenged by, difference, can diminish citizens' capacity for engaged pluralism (e.g. Sunstein, 2009), and the narrower pluralism of elite-driven democracy may seem the only option. According to Dewey (1937, p. 467), that option that does little to ensure the sustainability and development of democracy: "unless democratic habits of thought and action are part of the fiber of a people, political democracy is insecure". From this perspective, elitism and populism can be seen as two sides of the same coin -one predicated on the creation of committed followership, rather than engaged citizenship. In this sense, the future of democracy may depend greatly on the kind of citizen that citizens are invited and enabled to be.

Thinkers who argue that politics should mean more than party politics, and democracy more than representative democracy, have convincingly questioned the Schumpeterian narrative that prevailed in the last century. Current developments in participatory and deliberative democracy seem promising in terms of deepening citizenship, developing collective problem-solving capacity, and creating public spaces for engaged pluralism. New meanings and practices of democracy are, as ever, in the making. 


\section{Acknowledgments}

The author's work is supported by the What Works Scotland program, funded by the Economic and Social Research Council UK (ES/M 003922/1) and the Scottish Government. Special thanks to Adam Stewart (Convention of Scottish Local Authorities) for invaluable feedback on an earlier draft. Finally, the author is indebted to his students in two courses, Public Participation in Democracy and Governance, and Public Engagement in Policymaking and Governance, at the School of Social and Political Science of the University of Edinburgh. Their engagement in class discussions helped to shape the paper and their views on democratic innovation are a constant source of inspiration.

\section{References}

Baiocchi, G. (2005). Militants and citizens. The politics of participatory democracy in Porto Alegre. Stanford: Stanford University Press.

Baiocchi, G., \& Ganuza, E. (2014). Participatory Budgeting as if emancipation mattered. Politics and Society, 42(1), 29-50.

Baiocchi, G., \& Ganuza, E. (2017). Popular democracy: The paradox of participation. Stanford, CA.: Stanford University Press.

Barber, B.R. (2003). Strong democracy. Participatory politics for a new age (20th Anniversary Edition ed.). London: University of California Press.

Barnett, C. (2008). Convening publics: The parasitical spaces of public action. In K.R. Cox, M. Low, \& J. Robinson (Eds.), The SAGE handbook of political geography (pp. 403-418). London: SAGE Publications.

Bernstein, R.J. (2010). The pragmatic turn. Cambridge: John Wiley \& Sons.

Bohman, J. (1998). The coming of age of deliberative democracy. Journal of Political Philosophy, 6(4), 400-425.

Callon, M., Lascoumes, P., \& Barthe, Y. (2009). Acting in an uncertain world. An essay on technical democracy. Cambridge; London: Miт Press.

Carson, L., \& Martin, B. (1999). Random selection in politics. Westport, Ст.: Praeger Publishers.

Castells, M. (2012). Networks of outrage and hope: Social movements in the internet age. Cambridge: Polity Press.

Chambers, S. (2003). Deliberative democratic theory. Annual Review of Political Science, 6, 307-326.

Connolly, W.E. (2005). Pluralism. Durham and London: Duke University Press.

Cooke, B., \& Kothari, U. (Eds.). (2001). Participation. The new tyranny? London: Zed Books. 
Cornwall, A., \& Coelho, V.S.P. (2007). Spaces for change? The politics of citizen participation in new democratic arenas. London: Zed.

Dahl, R.A. (1982). Dilemmas of pluralist democracy. New Haven: Yale University Press.

Dahl, R.A. (1989a). Democracy and its critics. New Haven: Yale University Press.

Dahl, R.A. (1989b). Who governs? Democracy and power in an American city. New Haven: Yale University Press.

Dalton, R. (2004). Democratic Choices, Democratic Challenges : The Erosion of Political Support in Advanced Industrial Democracies. Oxford: Oxford University Press.

De Souza Briggs, X. (2008). Democracy as problem solving. Civic capacity in communities accross the globe. Cambridge and London: The MIT Press.

Dewey, J. (1916). Democracy and Education: An Introduction to the Philosophy of Education. E-book: Project Gutenberg.

Dewey, J. (1927). The public and its problems. Denver: A. Swallow.

Dewey, J. (1937). Democracy and educational administration. School and Society, 45, $457-467$.

Dewey, J. (1984). The later works, 1925-1927. Carbondale: Southern Illinois University Press.

Dryzek, J.S. (1990). Discursive democracy: Politics, policy, and political science. Cambridge: Cambridge University Press.

Dryzek, J.S. (2010). Foundations and frontiers of deliberative democracy. Oxford: Oxford University Press.

Dryzek, J.S., \& Niemeyer, S. (2010). Representation. In J.S. Dryzek (Ed.), Foundations and frontiers of deliberative democracy (pp. 42-65). Oxford: Oxford University Press.

Elstub, S. (2010). The Third Generation of Deliberative Democracy. Political Studies Review, 8(3), 291-307.

Elstub, S. (2014). Mini-publics: Issues and cases. In S. Elstub \& P. McLaverty (Eds.), Deliberative democracy: Issues and cases. Edinburgh: Edinburgh University Press.

Elstub, S., \& McLaverty, P. (2014). Introduction: Issues and cases in deliberative democracy. In S. Elstub \& P. McLaverty (Eds.), Deliberative democracy: Issues and cases (pp.1-16). Edinburgh: Edinburgh University Press.

Escobar, O. (2011). Public dialogue and deliberation: A communication perspective for public engagement practitioners. Retrieved from http://www.beltanenetwork.org/ resources/beltane-publications.

Escobar, O. (2014). Transformative practices: The political work of public engagement practitioners. (PhD Thesis), University of Edinburgh, Online Access https://www .era.lib.ed.ac.uk/handle/1842/9915, Edinburgh.

Fischer, F. (2000). Citizens, experts, and the environment: the politics of local knowledge. Durham [N.C.]; London: Duke University Press.

Fischer, F. (2009). Democracy and expertise: reorienting policy inquiry. Oxford: Oxford University Press. 
Forester, J. (1988). Planning in the Face of Power. California: University Presses of California, Columbia and Princeton.

Fournier, P., van der Kolk, H., \& Carty, R.K. (2011). When Citizens Decide: Lessons from Citizen Assemblies on Electoral Reform. Oxford: Oxford University Press.

Fraser, N. (1990). Rethinking the public sphere: A contribution to the critique of actually existing democracy. Social Text, 25/26, 56-80.

Fung, A. (2004). Empowered participation: reinventing urban democracy. Princeton, [N.J.]; Oxford: Princeton University Press.

Fung, A., \& Wright, E.O. (2003a). Deepening democracy: Institutional innovations in empowered participatory governance. London; New York: Verso.

Fung, A., \& Wright, E.O. (2003b). Thinking about empowered participatory governance. In A. Fung \& E.O. Wright (Eds.), Deepening democracy: Institutional innovations in empowered participatory governance (pp. 3-42). London; New York: Verso.

Grönlund, K., Bächtiger, A., \& Setälä, M. (Eds.). (2014). Deliberative mini-publics: Involving citizens in the democratic process. Colchester, UK: ECPR Press.

Gutmann, A., \& Thompson, D. (1996). Democracy and disagreement. Cambridge, MA: MIT Press.

Gylfason, T. (2013). Democracy on ice: a post-mortem of the Icelandic constitution. Retrieved from http://www.opendemocracy.net/thorvaldur-gylfason/democracy -on-ice-post-mortem-of-icelandic-constitution.

Habermas, J. (1975). Legitimation crisis. Cambridge, MA: Beacon Press.

Hendriks, C. (2005). Consensus Conferences and Planning Cells: Lay citizen deliberations. In J. Gastil \& P. Levine (Eds.), The deliberative democracy handbook: Strategies for effective civic engagement in the twenty-first century (pp. 80-110). San Francisco: Jossey-Bass.

Hendriks, C. (2011). The politics of public deliberation: citizen engagement and interest advocacy. Basingstoke: Palgrave Macmillan.

Hibbing, J.R., \& Theiss-Morse, E. (2002). Stealth democracy: Americans' beliefs about how government should work. Cambridge: Cambridge University Press.

Hirst, P. (1997). From statism to pluralism. Democracy, civil society and global politics. London: UCL Press.

Hirst, P. (1990). Representative democracy and its limits. Cambridge: Polity.

James, W. (1997). The writings of William James. Chicago: University of Chicago Press.

James, W. (2004). The meaning of Truth. EBook: Project Gutenberg.

Lee, C.W. (2015). Do-it-yourself democracy: The rise of the public engagement industry. New York: Oxford University Press.

Lippmann, W. (1927). The phantom public. New Brunswick, N.J.: Transaction.

Mansbridge, J., Bohman, J., Chambers, S., Estlund, D., Follesdal, A., Fung, A., Marti, J.L. (2010). The Place of Self-Interest and the Role of Power in Deliberative Democracy. Journal of Political Philosophy, 18(1), 64-100. 
Morrell, M.E. (2010). Empathy and democracy: Feeling, thinking, and deliberation. University Park, Pa.: Pennsylvania State University Press.

Mouffe, C. (1992). Dimensions of radical democracy: pluralism, citizenship, community. London: Verso.

Mouffe, C. (1996). Democracy, power, and 'the political'. In S. Benhabib (Ed.), Democracy and difference: Contesting the boundaries of the political (pp. 245-256). Princeton, N.J.: Princeton University Press.

Mutz, D.C. (2006). Hearing the other side: deliberative versus participatory democracy. Cambridge: Cambridge University Press.

Neblo, M.A., Esterling, K.M., Kennedy, R.P., Lazer, D.M.J., \& Sokhey, A.E. (2010). Who wants to deliberate -And why? American Political Science Review, 104(3), 1-18.

Norris, P. (2002). Democratic phoenix: Reinventing political activism. Cambridge: Cambridge University Press.

Norris, P. (2011). Democratic deficit: Critical citizens revisited. Cambridge: Cambridge University Press.

Parkinson, J. (2004). Why deliberate? The encounter between deliberation and new public managers. Public Administration, 82(2), 377-395.

Parkinson, J., \& Mansbridge, J. (2012). Deliberative systems: Deliberative democracy at the large scale. Cambridge: Cambridge University Press.

Pateman, C. (1970). Participation and democratic theory. Cambridge: Cambridge University Press.

Phillips, A. (1995). The politics of presence. Oxford: Oxford University Press.

Putnam, R.D. (2000). Bowling alone: the collapse and revival of American community. New York ; London: Simon \& Schuster.

Rescher, N. (1993). Pluralism. Against the demand for consensus. Oxford: Clarendon Press.

Roberts, J., \& Escobar, O. (2015). Involving communities in deliberation: A study of three citizens' juries on onshore wind farms in Scotland. Retrieved from www.climatex change.org.uk/reducing-emissions/citizens-juries-wind-farm-development -scotland.

Röcke, A. (2013). Framing citizen participation. Participatory Budgeting in France, Germany and the United Kingdom. Basingstoke and New York: Palgrave Macmillan.

Saward, M. (1998). The terms of democracy. Cambridge: Polity Press.

Saward, M. (2000). Democratic innovation: Deliberation, representation, and association. London: Routledge.

Saward, M. (2003). Democracy. Cambridge: Polity in association with Blackwell.

Schlosberg, D. (2008). The pluralist imagination. In J.S. Dryzek, B. Honig, \& A. Phillips (Eds.), The Oxford handbook of political theory (pp. 142-160).

Schumpeter, J.A. (1943). Capitalism, socialism, and democracy. London: G. Allen \& Unwin. 
Shapiro, I. (1999). Enough of Deliberation: Politics is About Interests and Power. In S. Macedo (Ed.), Deliberative Politics: Essays on Democracy and Disagreement. New York: Oxford University Press.

Sintomer, Y., \& Gret, M. (2005). The Porto Alegre experiment: Learning lessons for a better democracy. New York: Zed Books.

Smith, G. (2009). Democratic innovations: Designing institutions for citizen participation. Cambridge: Cambridge University Press.

Steiner, J. (2004). Deliberative Politics in Action: Analyzing Parliamentary Discourse: Cambridge University Press.

Sunstein, C.R. (2009). Going to extremes: How like minds unite and divide. Oxford: Oxford University Press.

Wampler, B. (2007). Participatory Budgeting in Brazil: Contestation, cooperation, and accountability. University Park, PA: Pennsylvania State University Press.

Warren, M. (2009). Governance-driven democratization. Critical Policy Studies, 3(1), 3-13.

Warren, M., \& Pearse, H. (Eds.). (2008). Designing deliberative democracy. The British Columbia Citizens' Assembly. Cambridge: Cambridge University Press.

Young, I.M. (2000). Inclusion and democracy. Oxford: Oxford University Press. 